\section{Vertebroplasty and Kyphoplasty Under Local Anesthesia: Review of 91 Patients}

\section{Lokal Anestezi Altında Uygulanan Vertebroplasti ve Kifoplastiler: 91 Hastanın Değerlendirilmesi}

\begin{abstract}
AIM: Vertebroplasty (VP) and kyphoplasty (KP) are minimally invasive methods for the treatment of vertebral compression fractures (VCF). In this study, we aimed to present our experience with VP and KP performed under local anesthesia and percutaneously.

MATERIAL and METHODS: Between 2002 and 2008, 91 patients (total 112 vertebrae) with VCF due to osteoporosis, tumor and trauma underwent VP or KP. After radiological and routine evaluations, all patients were operated under local anesthesia. Mean operation time was 20 minutes per vertebrae. We never stopped the operation because of intolerance of any patient and all of them were discharged on the day of operation or the next day except one.

RESULTS: All patients had severe back pain. Mean preoperative Visual Analogue Scale (VAS) score for pain was 8.3 and the mean postoperative value was 2.7. Mean anterior wall and mid-vertebral body heights increased by $32 \%$ and $43 \%$, respectively. The mean kyphotic angle decreased from 15.4 to 11.2. Cement leakage was observed in 4 patients and one of them underwent an open operation (decompression and stabilization) because of cement leakage to the epidural space. There was no other complication.
\end{abstract}

CONCLUSION: Vertebroplasty and kyphoplasty are safe, effective and minimally invasive procedures. Elderly patients can thefore avoid the potential complications of general surgery and be mobilized and discharged early.

KEYWORDS: Vertebroplasty, Kyphoplasty, Local anesthesia

ÖZ

AMAÇ: Vertebroplasti ve kifoplasti, vertebral kompresyon fraktürlerinin tedavisinde kullanılan minimal invaziv yöntemlerdir. Bu çalışmada, lokal anestezi altında ve perkütan olarak uyguladığımız vertebroplasti ve kifoplasti hastalarımızı sunmayı amaçladık.

YÖNTEM ve GEREÇ: 2002 ile 2008 yılları arasında, osteoporoz, tümör ve travma nedeniyle vertebral kompresyon fraktürü gelişen 91 hastaya (toplam 112 vertebra) vertebroplasti veya kifoplasti yapıldı. Radyolojik ve rutin biokimyasal değerlendirmelerin ardından tüm hastalar lokal anestezi altında opere edildiler. Ortalama operasyon zamanı her vertebra için 20 dakika idi. Hastaların intoleransı sebebiyle hiçbir operasyon yarıda kalmadı ve biri dışında tüm hastalar operasyon günü ya da ertesi gün taburcu edildiler.

BULGULAR: Tüm hastalarda ciddi sırt ağrısı mevcuttu. Preoperatif ortalama Görsel Analog Skoru (GAS) 8,3 iken postoperatif değer 2,7 idi. Cisim yüksekliğinde $\% 44$, anterior duvar yüksekliğinde \%32 artış elde edildi. Ortalama kifoz açısı 15,4 den 11,2 ye düştü. Dört hastada çimento sızması tespit edildi, bu hastalardan biri çimentonun epidural alana sızması nedeniyle açık operasyona dönüldü (dekompresyon ve stabilizasyon uyguland1). Başka komplikasyon izlenmedi.

SONUÇ: Vertebroplasti ve kifoplasti, perkütan ve lokal anestezi atında uygulanabilen, güvenli, efektif ve minimal invaziv yöntemlerdir. Bu sayede yaşlı hastalar genel anestezinin yol açabileceği komplikasyonlardan korunarak erken mobilize ve taburcu olabilirler.

ANAHTAR SÖZCÜKLER: Vertebroplasti, Kifoplasti, Lokal anestezi

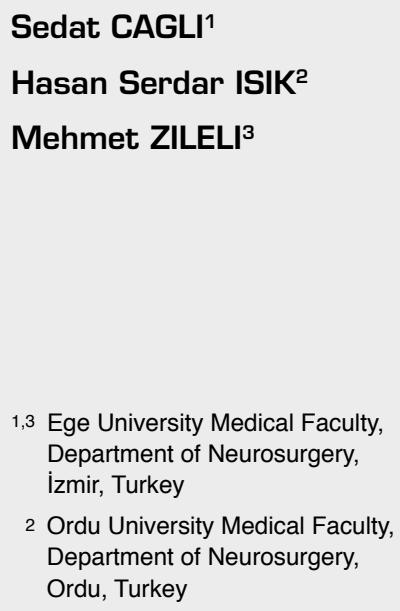

2 Ordu University Medical Faculty, Department of Neurosurgery, Ordu, Turkey

Received : 30.01 .2010

Accepted : 23.03.2010

Correspondence address:

Hasan Serdar ISIK

E-mail: serdarisik1@hotmail.com 


\section{INTRODUCTION}

Vertebral compression fractures (VCF) lead to morbidity and disability in the aging population. They can be caused by osteoporosis, malignancy or trauma (4-6,10,11,13-15,18-21,23,24). In the United States of America, approximately 750.000 osteoporotic VCF occur each year (4,9-11,21,23-25). Malignancies can affect the spinal column and cause fractures. It has been estimated that approximately $5 \%$ of cancer patients develop spinal metastasis each year and $85 \%$ of the metastasis cause spinal instability $(6,18,26)$. Traumas are another cause of VCF, especially in developing countries like Turkey $(5,22)$.

Patients with VCF often suffer back pain and the collapse of the fractured vertebral body can lead to spinal kyphosis. This spinal deformity leads to physical impairment, and decreased pulmonary capacity and mental health $(4-6,9,10,12,17)$. Traditional treatment of VCF consists of bed rest, analgesic drugs, bracing, physiotherapy or surgery to ensure stability of the spinal column $(4,6,11,12,19,20,22)$. Sometimes non-surgical treatment is not sufficient to resolve the symptoms but surgery may also cause severe problems in elder patients. Galibert and Deramond first described a minimal invasive procedure named vertebroplasty (VF) in 1987, taking these problems into account (27). This technique involves the percutaneous injection of polymethylmethacrylate (PMMA) into a fractured vertebral body. Kyphoplasty $(\mathrm{KF})$ is also a minimal invasive procedure designed to treatment VCF that involves percutaneous injection of an inflatable bone tamp into a fractured vertebral body under fluoroscopic guidance.

These procedures have gained popularity all around the world to treat VCF in recent years. In this study, we analyzed patients who underwent VP and KP under local anesthesia and percutaneously, retrospectively.

\section{MATERIAL and METHODS}

A total of $112 \mathrm{VP}$ and $\mathrm{KP}$ procedures were performed on 91 patients at Neurosurgery Department of Ege University Medical Faculty between 2002 and 2008. Most of the patients were transferred or referred to our clinic from the physiotherapy, oncology or emergency departments. All patients were evaluated with direct radiographs (thoracic and lumbar A-P and lateral radiographs), Computerized Tomography and Magnetic Resonance
Imaging and other routine biochemical parameters. We talked about the procedure with all patients and obtained their consent for the operation. After routine operation preparations, each patient was operated on in the operating room. After conscious sedation by intravenous analgesics, the patients were placed in the prone position on a radiolucent table after extending both arms. All operations were performed with the help of fluoroscopic guidance, percutaneously and under local anesthesia. VP or KP procedures were performed by standard techniques. The extrapedicular approach was used for the upper levels of thoracic 10 and the transpedicular approach was used for lower levels. No operation was stopped because of the patient's intolerance of the procedure. The distribution was 48 vertebroplasty procedures on 37 patients and 64 kyphoplasty procedures on 54 patients. Each patient was mobilized two or three hours after the operation and 90 of the 91 patients were discharged on the day of operation or the next day (some of them were transferred to the oncology or physiotherapy departments). Each patient was analyzed with pre-operative and post-operative VAS scores and radiologically. The anterior walls and mid -corpuscular body height and kyphotic angles were measured for radiological evaluation. The kyphotic angle and vertebral body height loss was measured on lateral radiographs. The anterior and mid-vertebral heights were measured as the distance between the upper and lower end plates at the anterior wall and in the center of the vertebral body. The normal heights for the anterior wall and mid-vertebral region were defined as the sum of the measurement of the corresponding heights of the adjacent superior and inferior non-fractured vertebrae divided by two. Kyphotic angles were measured using the Cobb technique (Figure 1). The mean follow-up period was 14 months, ranging from 4 to 32 months.

\section{RESULTS}

There were a total of 91 patients with 112 fractured vertebrae in the study; 61 patients were female and 30 male with a mean age of 67 (range from 28 to 81). We determined 52 osteoporotic patients with 64 fractured vertebrae, 28 malignancies with 37 fractured vertebrae and 11 traumatic patients with 11 fractured vertebrae. 73 patients had one-level fracture, 15 had two- and 3 patients had three-level fracture. To determine the pain relief, patients were evaluated by VAS scores. The mean pre operative VAS score was 8.3 and the mean post-operative score 
was 2.7. During long-term follow-up (12 months), the mean VAS score was found to be 3.4 for 64 patients. The pre-operative mean ratio of fractured vertebrae to estimated height for the anterior wall was 38\% and was restored to $26 \%$ post-operatively. This ratio for mid-vertebral body height was $32 \%$ pre-operatively and was restored $18 \%$ post-operatively. The mean vertebral body and anterior wall heights increased $44 \%$ and $32 \%$. The pre-operative mean kyphosis angle was 15.4 , and decreased to 11.2 post-operatively (Figure 1). After the 12-month follow-up period, the kyphotic angle increased to 14.1. All evaluations are summarized in Table I. PMMA cement leakage was detected in 4 patients. Three of them leaked to the intradiscal space and they were asymptomatic. There was only one patient where cement leakage was observed into the epidural space. This patient immediately underwent an open operation and decompression and stabilization were performed. During the follow-up period, we determined 12 new adjacent vertebrae fractures $(10.7 \%)$. There was no other complication in this study.

\section{DISCUSSION}

During the last decade, VP and KP have gained popularity for the treatment of VCF due to osteoporosis, malignancy or traumas. There are many reports in the literature that document the usefulness of these techniques $(4,5,10-12)$. Rapid regression of pain, restoration of vertebral body height and preservation of posture are especially important advantages of VP and KP (4,5,10-12,13-15). In addition, they can be performed percutaneously and under local anaesthesia. The aging of the population all around the world has brought increased attention on osteoporosis and malignancy and therefore fragility fractures $(9,10,11,15)$. The mean age of the patients was 67 in our study, similar to other reports $(9-13,18,19,23,25)$.

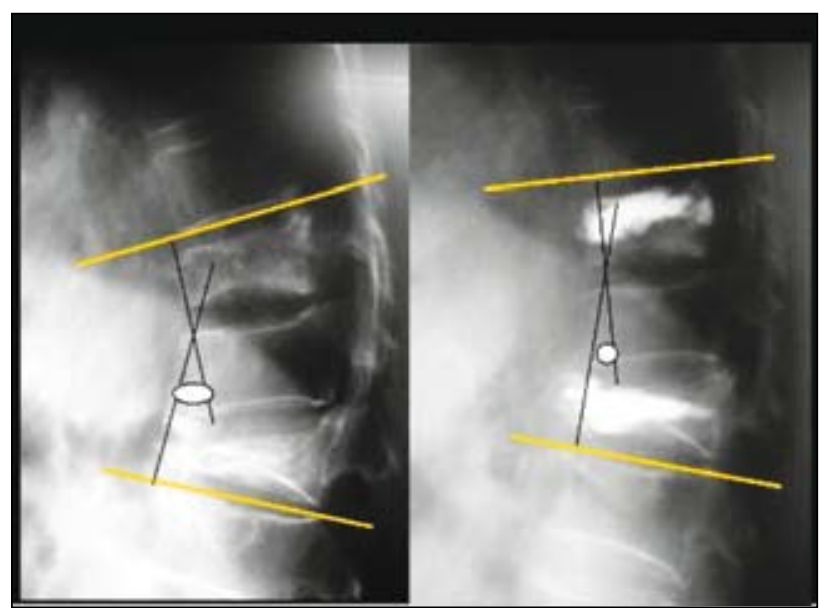

Figure 1: Vertebroplasty for $T 10$ and $T 12$ to restore the midvertebral body and anterior wall heights and changing of the kyphotic angles.

VCF cause severe back pain in the elderly population and leads to tenderness, limitation of mobility and loss of independence. Traditional treatments consist of analgesic drugs, especially non-steroidal anti-inflamatory drugs or long-term bed rest but are not sufficient for pain relief and they can cause other serious medical problems (4-6,1113). Rapid regression of pain and early mobilization are important factors in the recovery of VCF. VP and KP techniques have been shown to improve mobility and rapid regression of pain. Improvement in pain scores is dramatic in almost all series (46,10-13,15,18,19,23,26). Majd et al. reported $360 \mathrm{KP}$ procedures and Anselmetti et al. reported $283 \mathrm{VP}$ procedures with significant relief from pain $(27,28)$. We analyzed pain relief with VAS scores in this study and found the scores to decrease from 8.3 to 2.7. However, the VAS scores increased to 3.4 for 64 patients after a 12-month follow-up period. We believe that the increase in the VAS scores during the long-term follow-up period was due to the adjacent vertebrae fractures found in 12 patients. VP and KP

Table I: The Results of Outcomes

\begin{tabular}{|l|c|c|c|}
\hline & $\begin{array}{c}\text { Pre operative } \\
\mathbf{N = 9 1}\end{array}$ & $\begin{array}{c}\text { Post operative } \\
\mathbf{n = 9 1}\end{array}$ & $\begin{array}{c}\text { Follow-up period } \\
\text { (12 } \text { months) } \mathbf{n = 6 4}\end{array}$ \\
\hline Visual Analogue Scale Score & 8.3 & 2.7 & 3.4 \\
\hline Kyphotic Angle (degree) & 15.4 & 11.2 & 14.1 \\
\hline Anterior Wall Height (\%) & 38 & 26 & 31 \\
\hline Mid-vertebral Body Height $(\%)$ & 32 & 18 & 23 \\
\hline
\end{tabular}

n: number of patients 
are therefore useful methods for providing pain relief $(4-6,9,11-13,15,17-20,23,26)$.

The benefits of all minimally invasive neurosurgical procedures are shorter hospital stay, enhanced patient safety and lower post-operative morbidity compared with open surgical procedures. Whether the procedure requires general anesthesia or monitored anesthesia care, preoperative evaluation should be as through and comprehensive as for other surgical procedures $(7,8,14)$. Although VP and KP pose low surgical risk, the elderly patient population presents substantial anesthetic risk because of multiple comorbidities. These comorbidities, including cardiac disease, pulmonary compromise, urinary tract infection, poor nutritional status, narcotic dependency and limited mobility require careful pre-operative medical assessment and optimization. Cardiovascular and pulmonary disease may especially impair the ability to lie in a prone position for a long time during general anesthesia. In addition to the effects of the cardiac and pulmonary system, VCF in elderly patients affects the gastrointestinal system because of decreased abdominal space. VCF are caused by metastatic lesions and plasma cell malignancies associated with bone destruction. Bone marrow infiltration may result in anemia, neutropenia and bleeding $(7,8)$. It is therefore important for the results of biochemical parameters including blood count, electrolyte estimations and coagulation profile to be available before performing VP and KP procedures. In this study, we analyzed each patient with their radiological and biochemical parameters and the patients were also evaluated by our anesthesiologist.

Other authors have generally used either local or general anesthesia $(6,7,8)$ but there are no reports on using only local anesthesia with minimal sedation. In 2008, Lavalle et al reported 94 kyphoplasty cases performed with only general anesthesia. They pointed out that this form of anesthesia was chosen because it was felt that the elderly patient would not tolerate prone positioning (9). We talked about the procedure with all the patients in our study and obtained their consent first. No operation was stopped because of the type of anesthesia or intolerance of any of our patients.

Most VP and KP procedures can be performed with sedation and local anesthesia whereas; general anesthesia is required for $\mathrm{KP}$ and $\mathrm{VP}(6,16,21)$. General anesthesia is also used for the pat kyph reduced consciousness, extreme cases of anxiety, failed sedation and those with movement disorders and learning difficulties. Because of high dose sedation (over sedation) may be inappropriate in patients during KP; general anesthesia and airway protection are also needed for prolonged and uncomfortable procedures. In specific situations in which patients comorbidities prevent the use of sedatives and analgesics, the procedure can be performed using local anesthetics alone.

In our clinical practice, spontaneously breathing patients were placed in the prone position and mostly sedated using intravenous fentanyl $0,5 \mathrm{mcg}$. $\mathrm{kg}^{-1}$ and intravenous propofol $1 \mathrm{mg} \cdot \mathrm{kg}^{-1}$. In addition to sedation, $4-10 \mathrm{~mL} 0.5 \%$ bupivacaine was used as a local anesthetic. Electrocardiogram and oxygen saturation were continuously monitored. The blood pressure of the patient was measured every 5 minutes. Additional oxygen, $\left(5 \mathrm{~L} \mathrm{~min}^{-1}\right)$ was delivered to the patient during the procedure via an oxygen mask. We prefer to use intravenous midazolam $15 \mathrm{mcg} \cdot \mathrm{kg}^{-1}$ and small dose of intravenous ketamin (25 mg) (0,5 $\mathrm{mL}$ ) in patients with cardiac comorbidities to achieve adequate sedation during VP and KP.

Hanallah and Gibby used small-dose spinal anesthesia (one milliliter of plain $0,5 \%$ bupivacaine and $25 \mathrm{mcg}$ fentanyl injection into the subarachnoid space) in a high-risk patient who underwent KP (7). One case study describing the anesthetic management and one controlled study evaluating intraosseous lidocaine injection for intraoperative pain relief was found $(24,28)$. According to the author's opinion, the important factors for the selection of the anesthetic technique during the procedure (general anesthesia, regional anesthesia or local anesthesia with conscious sedation) are the type of procedure, number of segments to be augmented and comorbidity of the patients. We mostly prefer intravenous sedation achieved with propofol and fentanyl.

Although the advantages of VP and KP are rapid regression of pain, quick return to daily activities and decreasedoperativerisks, therearesomecomplications reported in the literature $(4,11-16,18,22-25)$. In 2009, Lee et al. reported a meta-analysis of complications for VP and KP (16). They categorized complications into 3 categories: (1) medical, (2) procedure related, (3) new vertebral fracture. They described the medical complications as non-cement embolism, 
stroke, cardiovascular complications, pneumonia and fever related to the patient's medical status. In our study, there was no medical complication. We belive that this is due to the type of anesthesia we used. Procedure-related complications consist of cement embolism, neurological deficit, discitis, dural tear and cement extravasation that can be seen during the procedure. Cement leakage is especially one of the most reported complications of these procedures $(4,11-16,18,22-25)$. Lee et al. also reported that the rate of asymptomatic or symptomatic cement leaks per number of patients treated was significantly higher for VP than for KP in all studies. In our study, there were 3 cement leakages for VP and 1 for KP. Of these 4 cases of cement leakage, one patient was symptomatic (because of leakage to the epidural space) and underwent open surgery (decompression and stabilization) immediately after the procedure. Other leaks were asymptomatic and through the intradiscal space. The third group of complications was occurrence of adjacent fractures. Various rates of adjacent fracture have been reported in previous studies $(4,11-14,16,17)$. We found 12 new adjacent fractures in a 14-month mean follow-up period.

In conclusion, KP or VP may be performed on an outpatient basis under local anesthesia with minimal sedation but patients with medical comorbidities should be observed for 24 hours. VP and KP are safe, effective and minimally invasive procedures performed percutaneously and under local anaesthesia. The elderly population suffering from back pain because of pathologic or traumatic vertebral compression fractures is especially suitable for this surgery. Elderly patients can therefore be protected from the complications of general anesthesia and mobilized and discharged earlier.

\section{REFERENCES}

1. Anselmetti GC, Corrao G, Monica PD, Tartaglia V, Monca A, Eminefendic H, Russo F, Tasetti I, Regge D: Pain relief following percutaneous vertebroplasty: Results of a series of 283 consecutive patients treated in a single instution. Cardiovasc Intervent Radiol 30: 441-447, 2007

2. Chen KY, Ma HI, Chiang YH: Percutaneous transpedicular vertebroplasty with polymethyl methacrylate for pathological fracture of the spine. Journal of Clinical Neuroscience 16: 1300-1304, 2009

3. Costa F, Ortolina A, Canlia A, Sassi M, De Santis A, Borroni M, Savoia G, Fornari M: Efficacy of treatment with percutaneous vertebroplasty and kyphoplasty for traumatic fracture of thoracolumbar junction. J Nurosurg Sci 53:13-17, 2009
4. Frost EAM, Johnson DM: Anesthetic considerations during vertebroplasty, kyphoplasty and intradiscal electrothermal therapy. International Anesthesiology Clinics 47(2):45-55, 2009

5. Gaitanis IN, Hadjipavlou AG, Katonis PG, Tzermiadionis MN, Pasku DS, Patwardhan AG: Balloon kyphoplasty for the treatment of pathological vertebral compressive fractures. Eur Spine J 14:250-260, 2005

6. Galibert P, Deromond H, Rosat P, Le Gars D: Preliminary note on the treatment of vertebral angioma by percutaneous acrylic vertebroplasty: Neurochirurgie 33:166-168, 1987

7. Hannallah M, Gibby E, Watson V: Fluoroscopy-guided, small dose spinal anesthesia for kyphoplasty, a collaborative effort between the anesthesiologist and interventional radiologist. Anesth Analg 106(4): 1329-1330, 2008

8. Heini PF, Orler R: Kyphoplasty for treatment of osteoporotic vertebral fractures. Eur Spine J 13:184-192, 2004

9. Khanna AJ, Reinhardt MK, Togawa D, Lieberman IH: Functional outcomes of kyphoplasty for the treatment of osteoporotic and osteolytic vertebral compression fractures. Osteoporos Int 17:817-826, 2006

10. Kim HW, Song JW, Kwan A, Kim H: Extreme multi-level percutaneous vertebroplasty for newly developed multiple adjacent compression fractures. J Korean Neurosurg Soc 45:378-380, 2009

11. Korovessis P, Hadjipavlou A, Repantis T: Minimal invasive short posterior instrumentation plus balloon kyphoplasty with calcium phosphate for burst and severe compression lumbar fractures. Spine 33(6):658-667, 2008

12. Krueger A, Bliemel C, Zettl R, Ruchholtz S: Management of pulmonary cement embolism after percutaneous vertebroplasty and kyphoplasty: A systematic review of the literature. Eur Spine J 18:1257-1265, 2009

13. Lavelle WF, Khaleal MA, Cheney R, Demers E, Carl AL: Effect of kyphoplasty on survival after vertebral compression fractures. The Spine J 8;763-769, 2008

14. Lee B, Franklin I, Lewis JS, Coombes C, Leonard R, Gishen $\mathrm{P}$, Stebbing J: The efficacy of percutaneous vertebroplasty for vertebral metastases associated with solid malignancies. Eur J Cancer 45:1597-1602, 2009

15. Lee MJ, Dumonski M, Cahill P, Stanley T, Park D, Singh K: Percutaneous treatment of vertebral compression fractures. Spine 34(11): 1228-1232, 2009

16. Lim BS, Chang UK, Youn SM: Clinical outcomes after percutaneous vertebroplasty for pathologic compression fractures in osteolytic metastatic spinal disease. J Korean Neurosurg Soc 45:369-374, 2009

17. Majd ME, Farley S, Holt RT: Preliminary outcomes and efficacy of the first 360 consecutive kyphoplasties for the treatment of painful osteoporotic vertebral compression fractures. Spine J 5:244-255, 2005

18. Mohit AA, Orr RD: Osteoporotic kırıklarda perkütan vertebral güçlendirme. Current Opinion in Orthopaedics, Turkish Edition 2(2):59-65, 2007

19. Pflugmacher R, Taylor R, Agarwal A, Melcher I, Disch A, Haras NP, Klosterman C: Balloon kyphoplasty in the treatment of metastatic disease of the spine: A 2 year prospective evaluation. Eur Spine J 17:1042-1048, 2008

20. Phillips FM: Minimally invasive treatments of osteoporotic vertebral compression fractures. Spine 28(155): 45-53, 2003 
21. Phillips FM, Erling H, Campbell-Hupp M, McNally T, Wetzel T, Gupta P: Early radiographic and clinical results of balloon kyphoplasty for the treatment of osteoporotic vertebral compression fractures. Spine 28(19):2260-2267, 2003

22. Ryu KS, Park CK: The prognostic factors influencing on the therapeutic effect of percutaneous vertebroplasty in treating osteoporotic vertebral compression fractures. J Korean Neurosurg Soc 45:16-23, 2009

23. Schubert A, Deogaonkar A, Lotto M, Niezguda J, Luciano M: Anesthesia for minimally invasive cranial and spinal surgery. J Neurosurg Anesthesiol 18(1):47-56, 2006

24. Sesay M, Dousset V, Liguoro D, Pehourca F, Caille JM, Mauratte $\mathrm{P}$ : Intraosseous lidocaine provides effective analgesia for percutaneous vertebroplasty of osteoporotic fractures. Can J Anaesth 49:137-143, 2002
25. Taş I, Hepgüler S, Zileli M, Çağlı S, İşlekel S: Osteoporotik vertebral kompresyon kırıklarının tedavisinde vertebroplasti ve kifoplasti. Osteoporoz Dünyasından 10(4):147-152, 2004

26. Taylor RS, Taylor RJ, Fritzell P: Balloon kyphoplasty and vertebroplasty for vertebral compression fractures. Spine 31(23): 2747-2755, 2006

27. Watts NB, Harris ST, Genant HK: Treatment of painful osteoporotic vertebral fractures with percutaneous vertebroplasty or kyphoplasty. Osteoporos Int 12:429-437, 2001

28. White SM: Anaesthesia for percutaneous vertebroplasty. Anaesthesia 57:1229-1230, 2002

29. Zhang R, Tao C, Yochum TR: Use of percutaneous vertebroplasty for intractable back pain associated with compression fracture in an 80 year-old female. J Manipulative Physiol Ther 31:319-322, 2008 